\title{
SEMINAL CARBOHYDRATE IN BOAR AND STALLION
}

\author{
S. BARONOS \\ ARC Unit of Reproductive Physiology and Biochemistry, Cambridge*
}

(Received 21st September 1970)

The seminal plasma of the boar is known to be rich in inositol but has a much lower content of fructose than that of either the bull or the ram, while stallion seminal plasma contains some inositol and hardly any fructose (Mann, 1954, 1964; Mann, Minotakis \& Polge, 1963). The purpose of the present study was to ascertain whether other carbohydrates, either free or bound, occur in boar and stallion seminal plasma.

Semen was collected by artificial vagina and the gel was removed. The seminal plasma, obtained by centrifugation at $2000 \mathrm{~g}$ for $10 \mathrm{~min}$, was separated into a dialysable and non-dialysable portion by dialysis at 2 to $5^{\circ} \mathrm{C}$ against glass-distilled water (five changes at $12-\mathrm{hr}$ intervals). Both the dialysable and non-dialysable portions were concentrated to the original volume of seminal plasma. For the analysis of free sugars, the dialysable portion was treated with barium hydroxide and zinc sulphate and passed through an ion-exchangeresin column composed of Amberlite IR-120 (H+) and Dowex AG-1 (OAc $\left.{ }^{-}\right)$ in exactly the same way as described in the study of human and bovine seminal plasma (Mann \& Rottenberg, 1966; Baronos, 1971). For the analysis of bound sugars, samples of both the dialysable and non-dialysable portions were subjected for $3 \mathrm{hr}$ to hydrolysis in $\mathrm{N}-\mathrm{H}_{2} \mathrm{SO}_{4}$ before de-ionization. Total carbohydrate was determined by the orcinol method (Vasseur, 1948), and fructose by the resorcinol method (Mann, 1946). Glucose and galactose were assayed enzymatically (Middleton \& Griffiths, 1957; Baronos, 1971). Glycerol and inositol were determined by gas-liquid chromatography after conversion to trismethylsilyl derivatives, using a SE 30 (methyl silicone gum) 5-ft long column (Selvendran \& Isherwood, 1970); before the determination of glycerol and inositol, the sugars were destroyed by treatment with hot $\mathrm{KOH}$ and the material passed through a column of Dowex $50\left(\mathrm{H}^{+}\right)$and Dowex $1\left(\mathrm{OAc}^{-}\right)$. The various carbohydrate constituents were identified by paper chromatography using ethyl acetate:pyridine:water $(8: 2: 1)$ as solvent and the silver reagent for spraying (Trevelyan, Proctor \& Harrison, 1950). The areas on chromatograms corresponding to galactose, mannose, glucose and fucose, as present in the nondialysable hydrolysed material, were eluted with water and their content determined in the eluates by the orcinol method.

As regards free sugars, chromatography has shown that boar seminal plasma contains fructose, inositol and a little glucose, and also an appreciable quantity

\footnotetext{
* Postal address: Animal Research Station, 307 Huntingdon Road, Cambridge GB3 0JQ, England.
} 
of two substances with exactly the same $R_{\mathrm{F}}$ value as authentic glycerol and galactose. Stallion seminal plasma had neither fructose nor galactose but contained some inositol as well as glucose and also a substance which behaved chromatographically as glycerol. As regards bound carbohydrate, this was mainly present in the non-dialysable portion of the seminal plasma; in the boar, it was composed of galactose, mannose and fucose in an approximately 10:3:1 ratio; in the stallion, it contained galactose, glucose, mannose and fucose in a ratio of $20: 2: 5: 1$.

\section{TABLE 1}

CONCENTRATION OF VARIOUS CARBOHYDRATES IN THE DIALYSABLE AND NON-DIALYSABLE PORTION OF BOAR AND STALLION SEMINAL PLASMA

\begin{tabular}{|c|c|c|c|c|c|c|}
\hline & $\begin{array}{c}\text { Total } \\
\text { orcinol- } \\
\text { reactive } \\
\text { carbohydrate }\end{array}$ & Fructose & Glucose & Galactose & Inositol & Glycerol \\
\hline $\begin{array}{l}\text { Boar seminal plasma } \\
\text { Dialysable, non-hydrolysed } \\
\text { portion }\end{array}$ & $\begin{array}{l}16 \text { to } 80 \\
(4)\end{array}$ & $\begin{array}{l}9 \text { to } 60 \\
\text { (4) }\end{array}$ & $\begin{array}{c}1 \text { to } 5 \\
(4)\end{array}$ & $\begin{array}{l}4 \text { to } 20 \\
(4)\end{array}$ & $\begin{array}{l}300 \text { to } 450 \\
\text { (3) }\end{array}$ & $\begin{array}{l}10 \text { to } 20 \\
\text { (3) }\end{array}$ \\
\hline $\begin{array}{c}\text { Non-dialysable, acid- } \\
\text { hydrolysed portion }\end{array}$ & $\begin{array}{l}100 \text { to } 130 \\
(4)\end{array}$ & - & $\begin{array}{c}\operatorname{trace} \\
(4)\end{array}$ & $\begin{array}{l}40 \text { to } 100 \\
(4)\end{array}$ & - & $\underset{(3)}{\operatorname{trace}}$ \\
\hline $\begin{array}{l}\text { Stallion seminal plasma } \\
\text { Dialysable non-hydrolysed } \\
\text { portion }\end{array}$ & $\begin{array}{l}20 \\
(1)\end{array}$ & $\begin{array}{l}\text { trace } \\
(1)\end{array}$ & $\begin{array}{l}12 \\
(1)\end{array}$ & - & $\begin{array}{l}127 \\
(1)\end{array}$ & $\begin{array}{l}23 \\
(1)\end{array}$ \\
\hline $\begin{array}{l}\text { Non-dialysable, acid- } \\
\text { hydrolysed portion }\end{array}$ & $\begin{array}{l}42 \\
(1)\end{array}$ & - & $\begin{array}{l}3 \cdot 1 \\
(1)\end{array}$ & $\begin{array}{l}36 \\
(1)\end{array}$ & - & $\begin{array}{c}\operatorname{trace} \\
(1)\end{array}$ \\
\hline
\end{tabular}

Results are expressed in $\mathrm{mg} / 100 \mathrm{ml}$; numbers of samples in parentheses.

Other analytical results are set out in Table 1. Among the carbohydrates listed in the Table is a substance tentatively identified as glycerol, not only by paper chromatography but by gas chromatography as well. The free carbohydrate of boar seminal plasma appears, therefore, to consist of both glycerol and galactose as well as inositol and fructose. Most of the galactose appears to be derived from the seminal-vesicle secretion; samples of that secretion collected directly from the glands of seventeen boars contained 6 to $22 \mathrm{mg}$ free galactose $/ 100 \mathrm{ml}$. Glycerol was determined in material pooled from three seminal vesicles: it contained $7.5 \mathrm{mg} / 100 \mathrm{ml}$, as determined by gas-liquid chromatography. Stallion seminal plasma can be seen from Table 1 to contain some glucose, as well as some glycerol and inositol.

As regards bound carbohydrate, it is evident from Table 1 that galactose is the main carbohydrate in both boar and stallion seminal plasma.

I would like to thank Mr I. Wilmut and Dr R. W. Allen for making the semen collections, and Professor T. Mann, G.B.E., F.R.s., for his valuable criticism.

\section{REFERENGES}

Baronos, S. (1971) The bound carbohydrate in bovine seminal plasma. F. Reprod. Fert. 25, (2). 
ManN, T. (1946) Studies on the metabolism of semen. 3. Fructose as a normal constituent of semina plasma. Site of formation and function of fructose in semen. Biochem. 7. 40, 481.

MANN, T. (1954) On the presence and role of inositol and certain other substances in the seminal vesicle secretion of the boar. Proc. R. Soc. B, 142, 21.

Mann, T. (1964) The biochemistry of semen and of the male reproductive tract, pp. 94-110. Methuen, London.

Mann, T., Minotakis, K. \& Polge, C. (1963) Semen composition and metabolism in the stallion and jackass. F. Reprod. Fert. 5, 109.

Mann, T. \& Rottenberg, D. A. (1966) The carbohydrate of human semen. F. Endocr. 34, 257.

Middleton, J. E. \& GRIFFiths, W. I. (1957) Radiocolorimetric micromethod for estimation of glucose in blood and C.S.F. using glucose oxidase. Br. med. F. ii, 1952.

Selvendran, R. R. \& Isherwood, F. A. (1970) Estimation of sucrose-6-phosphate and glucose-1,6diphosphate in tea leaves and strawberry leaves. Phytochemistry, 9, 533.

Trevelyan, W. E., Proctor, D. P. \& Harrison, J. S. (1950) Detection of sugars on paper chromatograms. Nature, Lond. 166, 444.

VASSEUR, E. (1948) A spectrophotometric study on the orcinol reaction with carbohydrates. Acta chem. scand. 2, 693 . 